\title{
Production of Cocktail of Lignolytic, Cellulolytic and Hemicellulolytic Enzymes by the Novel Bacterium Burkholderia Sp SMB1 Utilizing Rice Bran and Straw: Application in the Saccharification of Untreated Agro-Wastes for Bioethanol Production
}

\section{R.V. Beladhadi}

Gulbarga University

Kumar Shankar

Gulbarga University

S.K. Jayalakshmi

University of Agricultural Sciences Raichur

kuruba sreeramulu ( $\boldsymbol{\nabla}$ ksramu@rediffmail.com )

Gulbarga University Faculty of Science and Technology https://orcid.org/0000-0002-8773-1556

\section{Research Article}

Keywords: Burkholderia sp SMB1, Agro-wastes, Lignocellulolytic enzymes, Saccharification, fermentable sugars, Bioethanol

Posted Date: May 18th, 2021

DOI: https://doi.org/10.21203/rs.3.rs-440763/v1

License: (c) (i) This work is licensed under a Creative Commons Attribution 4.0 International License. Read Full License

Version of Record: A version of this preprint was published at Waste and Biomass Valorization on October 20th, 2021. See the published version at https://doi.org/10.1007/s12649-021-01607-7. 


\section{Abstract}

Purpose: This study focuses to assess the potentiality of the locally isolated Burkholderia sp SMB1. It was aimed for the cocktail of lignocellulolytic enzyme production involved in the depolymerization of the agro-wastes to release sugars for bioethanol production.

Methods: The optimization of enzyme cocktail (lignolytic, cellulolytic, hemicellulolytic) production by isolated bacterium utilizing inexpensive substrates like bran and straw of rice was done using response surface methodology. Further this cocktail secreted by the bacterium at optimized conditions was employed for saccharifying untreated agro-wastes for sugars production which were fermented to bioethanol by $S$. cerevisiae.

Results: This strain produced high titer of cellulase $(10.8 \mathrm{U} / \mathrm{mL})$, xylanase $(76 \mathrm{U} / \mathrm{mL})$, mannanase $(14.23$ $\mathrm{U} / \mathrm{mL})$, pectinase $(62.18 \mathrm{U} / \mathrm{mL})$ and laccase $(24.25 \mathrm{U} / \mathrm{mL})$ using rice bran at $7 \mathrm{pH}$ and $40{ }^{\circ} \mathrm{C}$ using $10 \%$ $(\mathrm{w} / \mathrm{v})$ of rice bran. The production of cocktail of enzymes was slightly increased by adding $\mathrm{CaCO}_{3}(2 \mathrm{mM})$ in the growth medium. This cocktail was able to hydrolyze untreated agro-wastes to release highest reducing sugars $28.5 \mathrm{~g} / \mathrm{L}$ using untreated corn husk after $24 \mathrm{~h}$ of saccharification process. These sugars of corn husk were fermented by $S$. cerevisiae to produce highest $9.04 \mathrm{gL}^{-1}$ bioethanol.

Conclusion: This paper represents the exploitation of the locally isolated strain for the production of lignocellulolytic enzymes using rice bran and straw for the first time promising the novelty of the study. This study helps in waste disposal process by valorizing the waste biomass to produce value added products like sugars, bioethanol and hence increases agricultural economy.

\section{Statement Of Novelty}

The production of the cocktail of lignolytic, cellulolytic and hemicellulolytic enzymes by the microorganisms has being the interesting topic because of its potentiality of utilizing the lignocellulosic agrowastes for the production of fermentable sugars. These sugars can be directly fermented to bioethanol without any detoxification as there may be less or no production of yeast inhibitors during the saccharification process through microbial or enzymatic process. Hence, the process becomes economically feasible as the steps required during fermentation (detoxification) may be reduced. Moreover, the isolated Burkholderia sp SMB1 becomes novel as it secretes high titer of enzymes after 24 $\mathrm{h}$. This work represents to be the first study on production of several lignocellulolytic enzymes by Burkholderia sp SMB1 strain utilizing several lignocellulosic agro-wastes. Thus, Burkholderia sp SMB1 strain shows the potentiality for its industrially application in biofuel industries as the cocktail of enzymes were utilized for the saccharification of agro-wastes to release fermentable sugars which are fermented to bioethanol by yeast strain.

\section{Introduction}


The lignocellulosic agro-wastes (LCAWs) are majorly composed of cellulose (35-50\%), hemicellulose $(25-35 \%)$, lignin (10-15\%) with small amount of extractives [1]. Cellulose and hemicellulose being the considerable component of LCAWs, because of its higher composition they may be utilized for the production of most valued products possessing various application like mono sugars which may be further fermented to biofuels, etc. [2]. The country like India produces about 350 million tons of agrowastes per annum, among which the major portion of it is burnt and used for land filling, which causes severe environmental issues [3]. One such crop is rice, which generates tons together bran and straw per year. These are being not disposed properly as they are burnt freely in the fields causing air pollution or left in the fields to get decomposed which reduces the crop yield and hence burdens the waste management processes [4]. The maximum worldwide production of the rice straw was estimated to be around 5.5 million tons per year [4]. In terms of production, rice is considered as second most important crop after wheat [5]. The usage of the residues of rice crop for the production of biofuels makes the process very useful and also helps in the waste management processes

Bioconversion of the rice residues to bioenergy or biofuels would be ecofriendly and also more economical rather than burning them. But the major drawback for their utilization is lignin which covers cellulose and hemicellulose part [6]. The production of bioethanol demands treatment to remove lignin and hydrolyze cellulosic and hemicellulosic part of LCAWs to produce fermentable sugars which are subsequently fermented to ethanol [7]. However, there are several pretreatments reported for this processes including chemical and thermochemical treatments which requires high energy and consequence negatively on the environment [3]. This may become cost freight, uneconomical and causing detrimental effect on the environment. Hence, utilizing microbes or enzymes for such processes may be very helpful as they are environmental friendly and requires less energy inputs and milder conditions when compared to other techniques [8]. Utilization of the synthetic enzymes or enzyme production using synthetic substrates may also not be the solution, as the production cost may increase [5]. So, isolating the bacteria producing cocktail of lignolytic, cellulolytic and hemicellulolytic (lignocellulolytic enzymes) with high titer of enzymes capable of hydrolyzing LCAWs into fermentable sugars sounds economically.

The micro-organisms producing lignocellulolytic enzymes viz., cellulase, xylanase, mannanase, pectinase, laccase would be favorable for the efficient utilization of the LCAWs. As, laccase helps in the lignin removal or hydrolysis process releasing polyphenols, makes the accessibility of cellulose and hemicellulose for their utilization [9]. Further cellulosic and hemicellulosic parts of the LCAWs may be utilized as substrate by cellulase and hemicellulase respectively [5] indicating the complete utilization of LCAWs. Hence, we have isolated the soil bacterium Burkholderia sp SMB1 producing lignocellulolytic enzymes utilizing LCAWs. However, there are several reports known till date on the isolation of the microbes viz. bacteria, fungi, actinomycetes, etc., producing lignocellulolytic enzymes [3, 5, 10-12]. But to date there are no single repots on the isolation of Burkholderia sp for production of cocktail of these lignocellulolytic enzymes by usage of rice agro-residues like bran and straw as substrate. Hence we report this work for the first time which sounds novel. Nevertheless, the fungi are known to produce high titer of enzymes, but there are various demerits for employing fungi for LCAWs utilization; they require longer 
time duration for the production of enzymes [5], also the isolation and enzyme extraction secreted by the fungi is a difficult process than that of bacterial. Further, there is also great chances for the process of contamination. Hence we have focused on bacterial isolation rather than fungi whose growth rate is faster than fungi. However, present work overcomes most of the reported studies, as it is able to secrete most of the lignocellulolytic enzymes after $24 \mathrm{~h}$ utilizing $10 \%$ of bran and straw of rice.

This study utilizes isolated Burkholderia sp SMB1 for the first time exploiting its capability for rice bran and straw utilization for the production of lignocellulolytic enzymes. The potentiality of the strain isolated was also checked to utilize several other agro-wastes for enzymes production. The optimization of their production was performed using response surface methodology (RSM). Also, we have studied effect of various metal ions and different nitrogen source on the enzymes production. The potentiality of the cocktail of crude enzymes secreted by Burkholderia sp was used to saccharify untreated LCAWs viz., corn husk, rice bran and straw for the fermentable sugars production which could be advantageous in bioethanol production. These sugars were further fermented to bioethanol.

\section{Materials And Methods}

\subsection{Chemicals and lignocellulosic agro-wastes}

Folin-ciocalteu reagent (FCR), 3,5- dinitro salicylic acid (DNS), carboxy methyl cellulose (CMC), pectin, xylan and 2,2- Azino-bis-(3-ethylbenzothiazoline-6-sulfonic acid) diammonium salt (ABTS), guaiacol , Bovine serum albumin (BSA) and other chemicals used for present work were of Himedia Chemicals, Mumbai, India, except that of the Locust bean gum (LBG), standard sugars (glucose, galactose, xylose) and polyphenols (gallic acid, ferulic acid) which were from Sigma Aldrich chemicals, India.

The bran and straws of rice and other LCAWs used were procured from the local market of Kalaburagi and Raichur, Karnataka, India. These LCAWs were collected separately in the plastic bags and were washed properly with distilled water. Further, they were oven dried until complete dryness. Then, were separately grinded in the domestic grinder until the particle sizes of 1-3 mm size. Later, they were stored aseptically in the air-tight containers until further usage.

\subsection{Isolation of the bacterium producing lignocellulolytic enzymes}

The soil sample from various LCAWs decaying local places around districts of Kalaburagi and Raichur, India, were collected in a sterile container. Further, these samples were added to sterile distilled water under sterile conditions and serially diluted to obtain the single colonies on the mineral salt medium (MSM) containing $2 \mathrm{mM}$ guaiacol (carbon source) as the major focus of isolating bacteria was to produce firstly laccase. Then, the reddish brown colored colonies of the bacteria obtained on such plates were allowed to grow on mineral salt agar plates containing $1 \%(\mathrm{w} / \mathrm{v})$ of other synthetic substrates (CMC 
for cellulase, xylan for xylanase, LBG for mannanase and pectin for pectinase) to check the ability of the organisms to utilize these substrates. Further, these plates were incubated at $37^{\circ} \mathrm{C}$ for $24-48 \mathrm{~h}$ and observed for the pure colonies growing on all the plates used.

For the maintenance of potent isolated strain capable on growing on all the synthetic substrates was incubated on the nutrient agar medium for $24 \mathrm{~h}$ and was stored in the refrigerator until next use.

\subsection{Identification of the isolated bacterium}

The cellular morphology of the potent isolated bacterium grown on the MSM with all the synthetic and natural (LCAWs) carbon source used separately was identified by Gram's staining. The biochemical characterization of the strain was done accordingly to the reported method $[10,13]$. The sequencing of the selected strain was carried by $16 \mathrm{~S}$ rRNA sequencing where the isolation of genomic DNA was done and the fragment of $16 \mathrm{~s}$ rRNA was amplified. Further sequencing was done using the universal primers and sequence analysis (Analysis was carried out by National Collection of Industrial Microorganisms, India). The construction of phylogenetic tree was done using MEGA version 7.0 and the gene was submitted to GenBank (NCBI) (National center for Biotechnology Information) to get accession number.

\subsection{Production of Lignocellulosic enzymes utilizing rice straw and husks}

The potent bacterium growing on all the synthetic substrates used was considered for the lignocellulolytic enzymes production by utilizing bran and straw of rice as substrate. The production of enzyme cocktail was performed in $250 \mathrm{~mL}$ Erlenmeyer flasks containing MSM adjusted with the required $\mathrm{pH}$ by using $\mathrm{NaOH}$ and $\mathrm{HCl}(0.1 \mathrm{~N})$ with required concentration of substrate (by RSM). The flasks were autoclaved at $121^{\circ} \mathrm{C}$ for $15 \mathrm{~min}$ and cooled. Then, the inoculum ( $\left.5 \% \mathrm{w} / \mathrm{v}\right)$ of bacterial isolate SMB1 was inoculated aseptically and incubated at temperature (according to RSM) under shaking conditions (200 rpm) in rotary shaker.

The Response Surface Methodology (RSM) with Central Composite Design (CCD) was used to know the optimum conditions viz., $\mathrm{pH}$ (factor 1), concentration (factor 2), time (factor 3 ) and temperature (factor4). A CCD model was constructed using Design Expert Software 13. The design was constructed with absorbance at $600 \mathrm{~nm}$ as response 1 (growth of the bacterium) with 30 runs. The maximum growth of the bacterium indicates maximum enzyme production. Hence, the optimum conditions showing maximum growth were considered for secretion of lignocellulolytic enzymes. The inoculum size and agitation were kept constant as they do not influence much on the production of enzymes.

The concentration of rice residues $(2.5-10 \% \mathrm{w} / \mathrm{v}$ ) was carried out in the shake flask (apart from RSM) and incubated at $40{ }^{\circ} \mathrm{C}$ for $24 \mathrm{~h}$ at $7 \mathrm{pH}$ under $200 \mathrm{rpm}$. After incubation, the crude enzyme was extracted. 
The content of the flasks after each run was filtered by sterile muslin cloth, followed by centrifugation at $10,000 \mathrm{rpm}$ for $10 \mathrm{~min}$ to procure the cocktail of crude enzyme. This cocktail containing maximized activities of enzymes was used for saccharification process of untreated LCAWs.

\subsection{Extraction and assay of lignocellulolytic enzyme, protein quantification}

The activities of cellulolytic and hemicellulolytic enzymes viz., cellulase, xylanase, mannanase and pectinase in the crude extract were assayed by DNS method [14] utilizing CMC, xylan, LBG and pectin as the corresponding substrates [15]. The enzymes activities were measured by the amount of reducing sugars released. The laccase activity was estimated as increase in the absorbance at $420 \mathrm{~nm}$ against ABTS [16].

One unit of the enzyme is expressed in $\mathrm{U} \mathrm{mL}^{-1}$ which is considered as the $\mu$ moles of the product released per minute per $\mathrm{mL}$ of the enzyme used. The concentration of the protein in the crude extract was quantified according to Lowry's et al., [17] where, Bovine serum albumin (BSA) was used as standard.

\subsection{Effect of salts and nitrogen source on production of enzymes}

The effect of different mineral salts ( $2 \mathrm{mM})$ viz., $\mathrm{CaCO} 3, \mathrm{MgCl}_{2}, \mathrm{NaCl}, \mathrm{FeSO}_{4} .7 \mathrm{H}_{2} \mathrm{O}, \mathrm{MgSO} 4.7 \mathrm{H}_{2} \mathrm{O}$ and $\mathrm{ZnSO}_{4}$. $7 \mathrm{H}_{2} \mathrm{O}$, different nitrogen sources $(0.2 \% \mathrm{w} / \mathrm{v})$ viz., $\mathrm{NH}_{4} \mathrm{NO}_{3}$, yeast extract, $\mathrm{NH}_{4} \mathrm{Cl}_{1} \mathrm{HH}_{4} \mathrm{SO}_{4}$ and hen's excreta were analyzed on the production of the lignocellulolytic enzymes. They were added in the growth medium separately and observed for the activities of the lignocellulolytic enzymes after $24 \mathrm{~h}$ of growth under optimized conditions which were measured as previously described (under section 2.5).

\subsection{Application of the cocktail of crude lignocellulolytic enzymes in saccharification of untreated LCAWs}

Since the potent isolated bacterium produces several lignocellulolytic enzymes, this cocktail was used for saccharifying untreated LCAWs viz., corn husk, rice bran and straw at the optimum conditions of saccharification viz., $50 \mathrm{mg}$ of protein (in crude extract) for $10 \%(\mathrm{w} / \mathrm{v})$ of corn husk at pH 7 and $40^{\circ} \mathrm{C}$ under static conditions for $24 \mathrm{~h}$. After incubation period, the hydrolyzed samples were filtered through muslin cloth, followed by centrifugation at $10,000 \mathrm{rpm}$ for $10 \mathrm{~min}$. This enzymatic hydrolysate was used for the estimating reducing sugars [14] and polyphenols by FCR method [18]. 


\subsection{Fermentation of the mono sugars in the un-detoxified enzymatic hydrolysate of LCAWs by $S$. cerevisiae for bioethanol production}

The enzymatic hydrolysate $(50 \mathrm{~mL})$ of LCAWs was added to the Erlenmeyer flask ( $250 \mathrm{~mL}$ ) with inoculum size of $10 \%(\mathrm{w} / \mathrm{v})$ of $S$. cerevisiae at $30^{\circ} \mathrm{C}, 5.5 \mathrm{pH}$ at $30^{\circ} \mathrm{C}$ under shaking conditions in rotary shaker for 72h. After fermentation process, the contents of the flasks were centrifuged at 10,000 rpm for $10 \mathrm{~min}$ at 4 ${ }^{\circ} \mathrm{C}$. The supernatant was distilled to collect the distillate according to Bala et al., [19] which was used for ethanol estimation by Gas chromatography.

\subsection{Analytical methods}

\subsubsection{High performance liquid chromatography (HPLC)}

The mono sugars and the polyphenols present in the enzymatic hydrolysate were analyzed by using HPLC (Shimadzu 10 ATVP).

For mono sugars analysis, HPLC with RI detector and X-bridge amide column (Waters, 4.6X150 mm) with the mobile phase of acetonitrile and water $(80: 20)$ was used at a flow rate of $1 \mathrm{~mL} / \mathrm{min}$. The sugars were identified and quantified by comparing with the peaks of standard sugars.

The polyphenols were identified and quantified by HPLC with UV detector and X-select C-18 column (Waters, 4.6X150 mm) with the mobile phase of methanol: water: acetic acid (80:18: 2) at the flow rate of $1 \mathrm{~mL} / \mathrm{min}$ by isocratic method. The peaks were compared with that of the standard compounds.

All the samples were filtered through the $0.2 \mu$ m nylon filter paper (Axiva membrane filters) before the analysis by HPLC which was performed at room temperature in both the cases of analysis.

\subsubsection{Gas Chromatographic (GC) analysis}

The distillate collected after fermentation of the enzymatic hydrolysate of LCAWs by S. cerevisiae was analyzed for ethanol by GC (Agilent 7890). The detector and the injector of the GC were maintained at $175^{\circ} \mathrm{C}$ with porapack column at $85^{\circ} \mathrm{C}$ equipped with flame ionization detector (FID).

\subsection{Yield and productivity of ethanol}

The yield of ethanol was calculated by ethanol produced per gram of glucose, whereas the productivity as the ethanol produced per no of hours of fermentation. 
All the experiments in this work were carried out in triplicates, wherein mean and \pm standard deviation (SD) were recorded by using MS Excel software 2016.

\section{Results And Discussion}

\subsection{Isolation and identification of the bacterium producing lignocellulolytic enzymes}

The isolates were firstly screened for laccase. The bacterial isolate growing on mineral salt medium containing guaiacol and also on other synthetic substrates viz., CMC, xylan, LBG and pectin were considered. Around 6 isolates were found to grow on all the synthetic substrates among which the potent strain (SMB1) possessing highest activity and ability to utilize LCAWs was sequenced. The alignment of the primary sequence was performed by the NCBI nucleotide blast search which depicts that the isolated strain SMB1 belongs to the Burkholderia sp. Figure S1 (supplementary file) depicts the Neighbor-joining phylogentic tree constructed using MEGA 7 software, where the analysis involved 9 nucleotide sequences. The phylogenetic tree predicts that the position of the isolate SMB1 is closest homology to Burkholderia sp. The nucleotide gene sequence was submitted to the GenBank, NCBI where the accession number MW774209 was obtained, so it could be identified as Burkholderia sp SMB1 strain. The biochemical characterization of the isolate was shown in Table 1. This strain was found to be Gramnegative and rod shaped bacteria. Our study lines with Ajao et al., [20] where the authors isolated Burkholderia cepacia strain from the refinery sludge. 
Table 1

Biochemical characterization of the isolated soil

bacterium Burkholderia sp SMB1 strain

\begin{tabular}{|ll|}
\hline Colonial characteristics & Results \\
\hline Gram's reaction & negative, rod shaped \\
\hline Catalase & + \\
Urease & + \\
Oxidase & + \\
\hline Indole & - \\
\hline Gelatin hydrolysis & + \\
\hline Starch hydrolysis & + \\
\hline Citrate utilization & + \\
\hline Glucose fermentation & + \\
\hline Lactose fermentation & + \\
\hline LCWAs- lignocellulosic agro-wastes
\end{tabular}

\subsection{Optimization for the cocktail of lignocellulolytic enzymes production}

The production of the cocktail of lignocellulolytic enzymes by the isolate Burkholderia sp SMB1 was optimized using RSM with CCD model with four independent factors: factor $1(\mathrm{pH})$, factor 2 (concentration), factor 3 (time) and factor 4 (temperature) as response 1 (absorbance at 600nm) (Supplementary Table S1). The figure (1a-f) depicts the optimized conditions ( $\mathrm{pH}$, substrate concentration, time and temperature) with response to the growth of the isolated bacterium. The figures depict the optimization conditions between factors A and B (Fig. 1a), factors A and C (Fig. 1b), factors A and $D$ (Fig. 1C), factors B and C (Fig. 1d), factors B and D (Fig. 1e) and factors $C$ and D (Fig. 1f) with the response 1. The growth conditions of the Burkholderia sp SMB1 was optimized as the maximized growth was found to be at $7 \mathrm{pH}, 40{ }^{\circ} \mathrm{C}$ after $24 \mathrm{~h}$ of incubation at $10 \%(\mathrm{w} / \mathrm{v})$ of substrate concentration shown in run 22 (Table S1). It reveals that that the bacterium was capable to withstand the temperature from $30^{\circ} \mathrm{C}$ to $50{ }^{\circ} \mathrm{C}, 5.5-7 \mathrm{pH}$ and utilize substrate concentration from 1-10\% (w/v) but maximum growth was found at $40^{\circ} \mathrm{C}, 7 \mathrm{pH}$ with $10 \%$ of substrate after $24 \mathrm{~h}$ (run 22). There was no growth at $\mathrm{pH} 1,3$ and 9 indicating the mesophilic nature of the strain. This may be because of the fact that at high or low $\mathrm{pH}$, there may be release of inhibitors from LCAWs which might be inhibiting the growth of the bacterium. However, the strain SMB1 was capable of withstanding the $\mathrm{pH}$ from $5.5-7,30-50^{\circ} \mathrm{C}$, but very least growth was observed at $\mathrm{pH} 5$ and $50^{\circ} \mathrm{C}$ revealing its optimum at $7 \mathrm{pH}$ and $40^{\circ} \mathrm{C}$. 
Since the maximum growth of the bacterium is directly indication of the maximum production of enzymes, the growth was considered as response factor in RSM. However, the production of the lignocellulolytic enzymes was carried out utilizing varying concentration of bran and straw of rice (2.5$10 \%$ w/v) (Fig. 2a \& b). The Fig. 2 depicts that the isolate SMB1 was capable of producing cellulase, xylanase, mannanase, pectinase and laccase with the substrates (rice bran and rice straw) utilized with the concentration from $2.5 \%$ to $10 \%(\mathrm{w} / \mathrm{v})$ But, the optimized production was at $10 \%(\mathrm{w} / \mathrm{v})$ for both the substrates. However, utilizing rice bran, maximum amount of the lignocellulolytic enzymes were produced cellulase $(10.8 \mathrm{U} / \mathrm{mL})$, xylanase $(76 \mathrm{U} / \mathrm{mL})$, mannanase $(14.23)$, pectinase $(62.18 \mathrm{U} / \mathrm{mL})$ and laccase $(24.25 \mathrm{U} / \mathrm{mL})$ comparatively with rice straw. Hence, the strain becomes potent producer of the lignocellulosic enzymes utilizing LCAWs as this study is first to be reported for the high titer of cocktail of lignocellulolytic enzymes production with this strain. However, some authors stated the lignocellulolytic enzymes production using various LCAWs by several fungi $[3,5,11-12]$ and certain bacteria $[10,21]$. But none of these authors reported all the lignocellulolytic enzymes reported in this study. Also Kerber et al., [5] reported the production of $53.6 \mathrm{U} / \mathrm{mL}$ of xylanase using barley bagasse which is lesser than that of our study. Nevertheless, Silva.et al., [12] reported Trichoderma reesei to secrete higher titer of xylanase ( $172 \mathrm{U} / \mathrm{g}$ dry substrate) and cellulase $(2.4 \mathrm{U} / \mathrm{g}$ dry substrate) by usage of pretreated carnauba straw after $72 \mathrm{~h}$ of incubation. But the author fails to produce the remaining enzymes produced by Burkholderia sp SMB1 and also the authors used pretreated substrate which is cost enhancing step. Furthermore, the fungi reported by Silva et al., [12] produced enzymes after $72 \mathrm{~h}$ of inoculation, which is three time higher than our study (strain SMB requires only $24 \mathrm{~h}$ ). Moreover, the production of the enzymes by fungi would be very tedious when compared with that of the bacteria. However, there were only few know for bacterial laccase production [22]. Hence, our work for the production of lignolytic, cellulolytic and hemicellulolytic cocktail would be most promising than other studies as time is the important factor for economically feasible.

The effect of different nitrogen source $(0.2 \% \mathrm{w} / \mathrm{v})$ on the production of cocktail of enzymes by the SMB1 strain was studied. The production of enzymes was enhanced by using ammonium nitrate followed by yeast extract, ammonium chloride and sulphate (Fig. 3a). However, the enzyme production was slightly reduced in the presence of hen excreta, but the strain has a capability of utilizing hen excreta as a nitrogen source. Further, different mineral salts were included in the growth medium to know their effect on the production of enzymes. It was clear that all the salts used in the study except $\mathrm{CaCO}_{3}$ and $\mathrm{FeSO}_{4} \cdot 7 \mathrm{H}_{2} \mathrm{O}$ had not much effected the production of enzymes, whereas calcium carbonate and ferrous sulphate enhanced the production of enzymes (data not shown). However, among both the salts, calcium carbonate enhanced the production of enzymes higher than that of the ferrous sulphate, hence, the concentration of the calcium carbonate (0.5-2 mM) was optimized (Fig. 3b). It was observed that the enzymes were found to be increasing with the increase in concentration of calcium carbonate till $2 \mathrm{mM}$. The maximum enhancement of the production of all the lignocellulolytic enzymes were found to be at 2 $\mathrm{mM}$ concentration of $\mathrm{CaCO}_{3}$. 
The potentiality of the Burkholderia sp SMB1 was expolited to utilize the several LCAWs for the production of cocktail of lignocellulolytic enzymes (Table S2). The other LCAWs used for the study were corn husk, sugarcane bagasses, wheat bran and peanut husk. However, Table S2 shows that the maximized amount of the cocktail of enzymes were secreted by Burkholderia sp SMB1 utilizing sugarcane bagasse and corn husk rather than rice residues or any other LCAWs used in this study which may be because of the chemical composition of LCAWs. But still we preferred using rice residues (bran and straw) because of their much availability in the local area of Raichur, India than compared with other LCAWs and also as it is the second largest crop produced throughout the world. Moreover, much of the work is performed on the enzyme production utilizing sugarcane bagasse [23-25]. Hence, we preferred the residues of the rice for the present work as their utilization may enhance the agricultural economy by helping the process of waste management by biomass valorization and also increases the income for farmers. The usage of several LCAWs depicts the potentiality of the isolated strain. Moreover, this strain capable of producing cocktail of lignocellulolytic enzymes may be used for the saccharification of the LCAWs for fermentable sugars production which may be further utilized in their fermentation for bioethanol production [19].

\subsection{Saccharification of the untreated LCAWs}

Since the isolated Burkholderia sp is capable of producing cocktail of enzymes, this was further used for the saccharification of the untreated LCAWs viz., corn husk, rice bran and rice straw. The crude cocktail of enzymes produced by SMB1 strain utilizing rice bran was used for the saccharification process. The LCAWs are made up of cellulose, hemicellulose and lignin. Since, lignin being the major hindrance for the saccharification process, the pretreatment becomes the most evitable step in this process [19]. There are several pretreatments viz., alkaline [26], acid [27] reported, but these kind of pretreatments produces several inhibitors like formic acid, acetic acid, furfural and 5-hydroxymethyl furfural which are toxic to the yeasts required for the process of fermentation of sugars to bioethanol $[26,28]$. The separation of these inhibitors before the fermentation of sugars to ethanol becomes the extra step which adds the cost freight. Even though the ionic liquids are considered as the green solvents but their use in the LCAWs pretreatment produces high salt concentration which inhibits the activity of cellulase and hence reduces the conversion of cellulose from LCAWs [29]. Additionally, the authors Yuan et al., [30] reported the adsorption $40 \%$ and $50 \%$ of carbohydrolysae on alkali and acid pretreated corn stover which may decrease the yield of the fermentable sugars and makes the process uneconomical. Hence, biological methods viz., employment of enzymatic (cocktail of lignocellulolytic enzymes) saccharification of the LCAWs would be more feasible as they produce no or less toxic compounds. The enzymes used for the saccharification must contain lignolytic, cellulolytic and hemicellulolytic for the efficient process of saccharification. The cellulase and the hemicellulases are necessary for cellulose and hemicellulose hydrolysis respectively to produce mono sugars. But the lignin being the hindrance for the saccharification process requires lignolytic enzyme for its hydrolysis, so that the cellulose and hemicellulose becomes available for their corresponding enzymes [16, 31]. Laccase being the lignolytic enzyme has the potential of hydrolyzing lignin into polyphenols and makes the accessibility of the 
surface of cellulose and hemicellulose in LCAWs for their conversion to fermentable sugars by the corresponding enzymes. As the cocktail produced by SMB1 strain contains laccase we focused to hydrolyze untreated LCAWs rather than undergoing pretreatment which would help in reducing the steps and ultimately the operating costs. Hence, LCAWs were saccharified using the cocktail secreted by Burkholderia sp SMB1. In spite of our previous work [1] where the pretreated LCAWs were saccharified by enzymes secreted by Sphingobacterium (Accession number KX856053), Burkholderia sp being most prominent as it secretes higher amount of cellulase and laccase and hence used for saccharifying untreated agro-wastes feasibly. Table 2 depicts the enzymatic saccharification of the untreated LCAWs to release highest total reducing sugars $(28.25 \mathrm{~g} / \mathrm{L})$ utilizing corn husk along with some of the polyphenols $(3.31 \mathrm{~g} / \mathrm{L})$ and comparative of our study with other reported works in producing reducing sugars. However, for more than $24 \mathrm{~h}(36 \mathrm{~h}$ ) of incubation the mono sugars were found to be reduced (data not shown) as the enzymes may be denaturized, solubility of lesser cellulosic form, no or lesser activity of the enzymes by the products hydrolyzed [20,32]. Hence the samples were collected right away after $24 \mathrm{~h}$. The major composition of the enzymatic hydrolysate of the untreated LCAWs in our study was glucose followed by xylose and galactose. The remaining amount of the reducing sugars present in the enzymatic hydrolysates (shown in Table 2) may be some un-fermentable oligosaccharides which were not analyzed in the present work. In spite of the lesser activity of cellulase in the cocktail secreted by SMB1 when compared with that of xylanase or other enzymes in the secretome, higher glucose was released. The reason for such type of results may be because of the synergistic activity of both cellulase and hemicellulase when combined [33]. Our results were in support with that of the results of Thomas et al., [33], as they have obtained lesser amount of reducing sugars when only cellulase was used and increased amount of reducing sugars when cocktail containing both cellulase and xylanase was used for saccharifying corn powder, corn stover and rice straw. Bala et al., [19] reported the release of 312.23 and $356.80 \mathrm{mg} \mathrm{g}^{-1}$ of mono sugars by saccharification of laccase pretreated Saccharum munja and sugarcane bagasse by cocktail of cellulolytic and hemicellulolytic enzymes secreted by Sprorotrichum thermophile which lies in support with the present work indicating the beneficial of the presence of laccase in the cocktail. The authors Kerber et al., [5] reported that the enzymatic saccharification of the untreated barley bagasse by the enzymes secreted by Trichoderma koningiopsis after $48 \mathrm{~h}$ was efficient than that of the enzymatic saccharification of acid and alkali pretreated. However, in any case of Kerber et al., [5] the reducing sugars are very lesser when compared with that of the present work. $10.30 \mathrm{gL}^{-1}$ of xylose was reported from the acid ( $2 \%$ sulfuric acid) pretreated rapseed straw at $131^{\circ} \mathrm{C}$ [34]. Even though utilization of acid by Lopez-Linares et al., [34], the xylose concentration was very less comparing with our work. The saccharification of the untreated LCAWs would be very beneficial as they reduce the energy requirement, time consumption and hence becomes economical feasible. Some of the author [35-36], used the commercial cellulase for the saccharifying rice husk and soybean hull respectively, which would be economically unviable using commercial enzymes, as they may add extra cost for the process. Hence, utilizing cocktail of enzymes secreted by Burkholderia sp SMB1 favors the present work to be efficient. This characteristic of Burkholderia sp SMB1 strain makes it potent candidate for the secretion of cocktail of enzymes used in the saccharification of untreated biomass. Nevertheless, pretreatment of LCAWs before enzymatic hydrolysis may slightly enhance the release of sugars but these process may add cost 
freight. Hence, in this work we have not undergone any pretreatment process as we were more focused for the potentiality of the cocktail secreted by Burkholderia sp SMB1 for saccharifying untreated LCAWs rather than pretreated.

Table 2

HPLC analysis of reducing sugars and polyphenols present in the enzymatic hydrolysate of LCAWs saccharified by crude lignocellulolytic enzyme cocktail secreted by Burkholderia sp SMB1

\begin{tabular}{|c|c|c|c|c|c|c|c|c|}
\hline & \multicolumn{4}{|c|}{ Reducing sugars (g/L) } & \multicolumn{3}{|c|}{ Polyphenols (g/L) } & \multirow[t]{2}{*}{ Reference } \\
\hline & Total & Glucose & Xylose & Galactose & Total & $\begin{array}{l}\text { Gallic } \\
\text { acid }\end{array}$ & $\begin{array}{l}\text { Ferulic } \\
\text { acid }\end{array}$ & \\
\hline Corn husk & $\begin{array}{l}28.25 \pm \\
1.21\end{array}$ & $\begin{array}{l}18.5 \pm \\
0.21\end{array}$ & $\begin{array}{l}5.12 \pm \\
0.31\end{array}$ & $1.1 \pm 0.08$ & $\begin{array}{l}3.31 \\
\pm \\
0.81\end{array}$ & $\begin{array}{l}2.25 \\
\pm \\
0.12\end{array}$ & $\begin{array}{l}0.81 \pm \\
0.13\end{array}$ & $\begin{array}{l}\text { Present } \\
\text { study }\end{array}$ \\
\hline Rice bran & $\begin{array}{l}22.42 \pm \\
0.42\end{array}$ & $\begin{array}{l}14.84 \pm \\
0.13\end{array}$ & $\begin{array}{l}3.84 \pm \\
0.11\end{array}$ & $\begin{array}{l}0.58 \pm \\
0.05\end{array}$ & $\begin{array}{l}1.84 \\
\pm \\
0.05\end{array}$ & $\begin{array}{l}0.84 \\
\pm \\
0.23\end{array}$ & $\begin{array}{l}0.54 \pm \\
0.11\end{array}$ & $\begin{array}{l}\text { Present } \\
\text { study }\end{array}$ \\
\hline Rice straw & $\begin{array}{l}13.24 \pm \\
0.23\end{array}$ & $\begin{array}{l}7.45 \pm \\
0.09\end{array}$ & $\begin{array}{l}3.33 \pm \\
0.21\end{array}$ & $\begin{array}{l}1.21 \pm \\
0.31\end{array}$ & $\begin{array}{l}2.31 \\
\pm \\
0.21\end{array}$ & $\begin{array}{l}1.08 \\
\pm \\
0.05\end{array}$ & $\begin{array}{l}0.68 \pm \\
0.21\end{array}$ & $\begin{array}{l}\text { Present } \\
\text { study }\end{array}$ \\
\hline $\begin{array}{l}\text { aaice } \\
\text { straw }\end{array}$ & $\begin{array}{l}8.16 \\
\mathrm{mg} / \mathrm{mL}\end{array}$ & ND & ND & ND & ND & ND & ND & $\begin{array}{l}\text { Thomas et } \\
\text { al., } 2016\end{array}$ \\
\hline $\begin{array}{l}{ }^{b} \text { Rice } \\
\text { straw }\end{array}$ & $\begin{array}{l}17.35 \\
\mathrm{mg} / \mathrm{mL}\end{array}$ & ND & ND & ND & ND & ND & ND & $\begin{array}{l}\text { Thomas et } \\
\text { al., } 2016\end{array}$ \\
\hline $\begin{array}{l}\text { cBarley } \\
\text { bagasse }\end{array}$ & $\begin{array}{l}13.3 \pm \\
0.74\end{array}$ & $\begin{array}{l}5.9 \pm \\
0.10\end{array}$ & $\begin{array}{l}2.6 \pm \\
0.07\end{array}$ & ND & ND & ND & ND & $\begin{array}{l}\text { Kerber et } \\
\text { al., } 2021\end{array}$ \\
\hline $\begin{array}{l}{ }^{d} \text { Barley } \\
\text { bagasse }\end{array}$ & $\begin{array}{l}11.3 \pm \\
0.21\end{array}$ & $\begin{array}{l}5.5 \pm \\
0.53\end{array}$ & $\begin{array}{l}2.4 \pm \\
0.07\end{array}$ & ND & ND & ND & ND & $\begin{array}{l}\text { Kerber et } \\
\text { al., } 2021\end{array}$ \\
\hline $\begin{array}{l}\text { eBarley } \\
\text { bagasse }\end{array}$ & $\begin{array}{l}12.8 \pm \\
0.11\end{array}$ & $\begin{array}{l}5.2 \pm \\
0.27\end{array}$ & $\begin{array}{l}3.4 \pm \\
0.08\end{array}$ & ND & ND & ND & ND & $\begin{array}{l}\text { Kerber et } \\
\text { al., } 2021\end{array}$ \\
\hline \multicolumn{9}{|c|}{ The values are mean \pm SD of three readings } \\
\hline \multicolumn{9}{|c|}{ ND - not detected/reported, LCAWs-lignocellulosic agro-wastes } \\
\hline \multicolumn{9}{|c|}{$\begin{array}{l}\text { a When cellulase alone was used for saccharification and b- when both cellulase and xylanase } \\
\text { cocktail was used for the saccharification of rice straw by Thomas et al., } 2016 \text {. }\end{array}$} \\
\hline \multicolumn{9}{|c|}{$\begin{array}{l}\text { c, d \& e -are saccharification of the untreated, acid and alkali treated barley bagasse by the author } \\
\text { Kerber et al., } 2016 \text {. }\end{array}$} \\
\hline
\end{tabular}

As the cocktail utilized for saccharification contains laccase, lignin may be hydrolyzed to release polyphenols (Table 2). Also, the major polyphenols found in the enzymatic hydrolysate were gallic acid and ferulic acid of the total amount of polyphenols determined in the hydrolysate. These polyphenols are found to be antioxidative in nature [18] which may be further separated and used as antioxidants. Hence 
our work becomes efficient as it is capable of producing lignocellulolytic enzymes which are able to hydrolyze untreated LCAWs to co-produce fermentable sugars along with polyphenols which may be used in the biofuel industry and as natural antioxidants respectively.

\subsection{Fermentation of the mono sugars to bioethanol by S. cerevesiae}

The mono sugars present in the enzymatic hydrolysate of the LCAWs were fermented to bioethanol by using $S$. cerevisiae cells. The Fig. 4 depicts the utilization of the mono sugars present in the hydrolysate of corn husk for the bioethanol production by the yeast strain used in this study. It was observed that maximum of $9.04 \mathrm{gL}^{-1}$ of ethanol was produced after $72 \mathrm{~h}$ of fermentation using hydrolysate of corn husk (Fig. 4). However, $7.35 \mathrm{gL}^{-1}$ and $3.7 \mathrm{gL}^{-1}$ of ethanol was produced utilizing the enzymatic hydrolysate of untreated rice bran and rice husk respectively (data not shown). It was clear from the study that $S$. cerevisiae was able to utilize only hexoses (glucose and galactose were found to be completely utilized) and left out un-utilized xylose in the fermentation broth as such (Fig. 4). The left out total reducing sugars in the fermentation broth may be because of the sugar utilization property of the yeast strain used (hexose fermenting). Our results were in support with the study of Patel et al., [37] (2017), wherein un-utilization of the pentoses and some reducing sugars present in the sugarcane bagasse hydrolysate by $S$. cerevisiae. The yield of the ethanol was $0.488 \mathrm{gg}^{-1}$ with the productivity of $0.125 \mathrm{gL}^{-}$ ${ }^{1} \mathrm{~h}^{-1}$. Hence, this study with the good yield of ethanol would be more feasible process.

\section{Conclusion}

The isolate Burkholderia sp SMB1 can be exploited for the production of lignocellulolytic enzymes utilizing several lignocellulolsic of agro-wastes as carbon source. This study was primarily focused to reduce the cost of enzymes production process by using inexpensive sources rather than using synthetic substrates. For the economical bioconversion of the LCAWs into biofuels and other valued products the enzyme cocktail (lignolytic, cellulolytic and hemicellulolytic) should be produced by the microorganisms. Hence the Burkholderia sp producing the cocktail of lignocellulolytic enzymes becomes potential and most promising strain in the biofuel industry as it can hydrolyze untreated biomass to release fermentable sugars reducing the steps required for its pretreatment and also these sugars are directly fermented to bioethanol without any detoxification process making the process cost effective.

\section{Declarations}

\section{Conflict of interest}

The authors declare that there is no conflict of interest. 


\section{Acknowledgement}

The authors acknowledge UGC-BSR SAP-II and DBT, New Delhi, India for funding this work in the form of fellowship. The authors are also thankful for CSIR-SRF, New Delhi, India for funding.

\section{References}

1. Shankar, K., Kulkarni, N.K., Jayalakshmi, S.K., Sreeramulu, K.; Saccharification of the pretreated husks of corn, peanut and coffee cherry by the lignocellulolytic enzymes secreted by Sphingobacterium ksn for the production of bioethanol. Biomass Bioenerg. 127, 105298 (2019).

2. Dulf, F.V., Vodnar, D.C., Dulf, E.H., Pintea, A.; Phenolic compounds, flavonoids, lipids and antioxidant potential of apricot (Prunus armeniaca $\mathrm{L}$ ) pomace fermented by two filamentous fungal strains in solid state system. Chem. Cent. J. 11, 92, (2017). https://doi.org/10.1186/s13065-017-0323-z

3. Pamidipati, S., Ahmed, A.; Degradation of Lignin in Agricultural Residues by locally Isolated Fungus Neurospora discrete. Applied Biochem Biotechnol. (2016). DOI 10.1007/s12010-016-2302-6.

4. Hung, N.V., Maguyon-Detras M.C., Migo, M.V., Quilloy, R., Balingbing, C., Chivenge, P., Gummert, M.; Rice Straw Overview: Availability, Properties, and Management Practices. Sustainable Rice Straw Manag, (2020). https://doi.org/10.1007/978-3-030-32373-8_1.

5. Kerber, C.M.da,C., Rasbold, L.M., Heinen, P.R., Henn, C.M.A., Silva, J.L.da.C., Simão Rde, C.,Simões, M.R., Kadowaki, M.K.; Production of Hemicellulolytic Enzymes by a Novel Trichoderma koningiopsis 20I2A1M and Its Application in the Saccharification of Barley Bagasse. Waste Biomass Valoriz. (2021). https://doi.org/10.1007/s12649-021-01401-5.

6. Tsegaye, B., Balomajumder, C., Roy, P.; Biodelignification and hydrolysis of rice straw by novel bacteria isolated from wood feeding termite. 3 Biotech. (2018). https://doi.org/10.1007/s13205-0181471-0.

7. Pamidipati, S., Ahmed, A.; Cellulase stimulation during biodegradation of lignocellulosic residues at increased biomass loading. Biocatlys Biotransform. (2018). DOI: 10.1080/10242422.2018.1508284.

8. Arora, A., Priya, S., Sharma, P., Sharma, S., Nain, L.; Evaluating biological pretreatment as a feasible methodology for ethanol production from paddy straw. Agric. Biotechnol 2016; https://doi.org/10.1016/j.bcab.2016.08.006.

9. Sondhi, S., Sharma, P., Saini, S., Puri, N., Gupta, N.; Purification and Characterization of an extracellular thermo-alkali-stable, metal tolerant laccase from Bacillus tequilensis PLoS ONE. 9:e96951. (2014). https ://doi.org/10.1371/journ al.pone.00969 51.

10. Angural, S., Kumar, A., Kumar. D., Warmoota, R., Sondhi, S., Gupta, N.; Lignolytic and hemicellulolytic enzyme cocktail production from Bacillus tequilensis LXM 55 and its application in pulp biobleaching. Bioproc. Biosyst. Eng. (2020). https://doi.org/10.1007/s00449-020-02407-4.

11. Anu, Kumar, A.A., Singh, D., Kumar, V., Singh, B.; Production of cellulolytic enzymes by Myceliophthora thermophile and their applicability in saccharification of rice straw. Biomass Convers Biorefin. 
(2020). https://doi.org/10.1007/s13399-020-00783-1.

12. da Silva,.F.L., Magalhães, E.R.B., de Sá Leitão, A.L.O., dos Santos, E.S.; Production of lignocellulolytic enzymatic complex using pretreated carnauba straw as carbon source and application on sugarcane bagasse hydrolysis. Biomass Convers Biorefin. (2020). https://doi.org/10.1007/s13399-020-00815W.

13. Holt, J.G., Krieg, N.R., Sneath, P.H.A., Staley, J.T., Williams, S.T.; Bergey's manual of determinative bacteriology. Williams and Wilkins, Baltimore. (1994).

14. Miller, G.L.; Use of dinitrosalicylic acid reagent for determination of reducing sugar. Chem. 31, 426428 (1959).

15. Salim, A.A., Grbavčić, S., Šekuljica, N., Stefanović, A., Jakovetić-Tanasković, S., Luković, N., KneževićJugović, Z.; Production of enzymes by a newly isolated Bacillus TMF-1 in solid state fermentation on agricultural by-products: The evaluation of substrate pretreatment methods. Bioresour. Technol 228, 193-200. (2017). https://doi.org/10.1016/j.biortech.2016.12.081.

16. Giacobbe, S., Pezzella, C., Lettera, V., Sannia, G.; Laccase pretreatment for agrofood wastes valorization. Bioresour Technol. 265, 59-65. (2018).

17. Lowry, H., Rosembrough, N.J., Farr, A.L., Randall, R.J.; Protein measurement with the folin phenol reagent. J. Biol. Chem. 193, 265-275 (1951).

18. Vijayalaxmi,S., Jayalakshmi, S.K., Sreeramulu, K.; Polyphenols from different agricultural residues: extraction, identification and their antioxidant properties. J Food Sci Technol. 52, 2761-2769 (2015).

19. Bala, A., Singh, B.; Development of an environmental-begin process for efficient pretreatment and saccharification of Saccharum biomasses for bioethanol production. Energy. (2018). https://doi.org/10.1016/j.renene.2018.06.033.

20. Ajao, A.T., Yakubu, S.E., Umoh, V.J., Ameh, J.B.; Enzymatic Studies and Mineralization Potential of Burkholderia cepacia and Corynebacterium kutscheri Isolated from Refinery Sludge. J Micro Res. 4(2), 29-42 (2014).

21. Abdelgalil, S.A., Soliman, N.A. Abo-Zaid, G.A.; Abdel-Fattah, Y.R.; Bioprocessing strategies for cost-effective large-scale production of bacterial laccase from Lysinibacillus macroides LSO using bio-waste. Int. J Env. Sci Tech. (2021). https://doi.org/10.1007/s13762-021-03231-3.

22. Suman, S.K., Dhawaria, M., Tripathi, D., Raturi, V., Adhikari, D.K., Kanaujia, P.K.; Investigation of lignin biodegradation by Trabulsiella isolated from termite gut. Int. Biodeterior. Biodegrad. 112, 12-17 (2016). https://doi.org/10.1016/j.ibiod.2016.04.036.

23. Maibam, P.D., Maiti, S.K.; A Strategy for Simultaneous Xylose Utilization and Enhancement of Cellulase Enzyme Production by Trichoderma reesei Cultivated on Liquid Hydrolysate Followed by Induction with Feeding of Solid Sugarcane Bagasse. Waste Biomass Valor. 11, 3151-3160 (2020).

24. Sharma, R., Kocher, G.S., Rao, S.S., Oberoi, H.S.; Improved Production of Multi-component Cellulolytic Enzymes Using Sweet Sorghum Bagasse and Thermophilic Aspergillus terreus RWY Through Statistical Process Optimization. Waste Biomass Valor. 11, 3355-3369 (2020). 
25. Singh, N., Devi, A., Jaryal, R., Rani, K.; An Ecofriendly and Efficient Strategy for Cost Effective Production of Lignocellulotic Enzymes. Waste Biomass Valor. 9, 891-898 (2018).

26. Ko, J.K., Ximenes, E., Kim, Y., Ladisch, M.R.; Adsorption of enzyme onto lignins of liquid hot water pretreated hardwoods. Biotechnol. Bioeng. 9999, 1-11. (2014). https://doi.org/10.1002/bit.25359.

27. Ang, T.N., Ngoh, G.C., Seak, A., Chua, M.; Comparative study of various pretreatment reagents on rice husk and structural changes assessment of the optimized pretreated rice husk. Bioresour. Technol. 135, 116-119. (2013). https://doi.org/10.1016/j.biortech.2012.09.045.

28. Wang, X., Tsang, Y.F., Li, Y., Ma, X., Cui, S., Zhang, T.A., Hu, J., Gao, M.T.; Inhibitory effects of phenolic compounds of rice straw formed by saccharification during ethanol fermentation by Pichia stipitis. Bioresour. Technol. 244, 1059-1067, (2017). https://doi.org/10.1016/j.biortech.2017.08.096.

29. Motamedi, E., Fatemeh, S., Motahar, S., Maleki, M., Kavousi, K., Ariaeenejad, S., Moosavi-Movahedi, A.A., Salekdeh, G.H.; Upgrading the enzymatic hydrolysis of lignocellulosic biomass by immobilization of metagenome-derived novel halotolerant cellulase on the carboxymethyl cellulosebased hydrogel. Cellulose. (2021). https://doi.org/10.1007/s10570-021-03727-

30. Yuan, Y., Zhai, R., Li, Y., Chen, X., Jin, M.; Developing fast enzyme recycling strategy through elucidating enzyme adsorption kinetics on alkali and acid pretreated corn stover. Biotechnol Biofuels. 11, 316 (2018). https://doi.org/10.1186/s13068-018-1315-5.

31. Rajak, R.C., Banerjee, R.; Enzyme mediated biomass pretreatment and hydrolysis: a biotechnological venture towards bioethanol production. RSC Adv. 6, 61301-61311 (2016). https://doi.org/10.1039/C6RA09541K.

32. Pandiyan, K., Tiwari, R., Singh, S., Nain, P.K.S., Rana, S., Arora, A., Singh, S.B., Nain, L., Optimization of Enzymatic Saccharification of Alkali Pretreated Parthenium sp . Using Response Surface Methodology. Enz. Res 764898, 8. (2014). http://dx.doi.org/10.1155/2014/764898.

33. Thomas, L., Parameswaran, B., Pandey, A.; Hydrolysis of pretreated rice straw by an enzyme cocktail comprising acidic xylanase from Aspergillus for bioethanol production. Renew. Energy. 98, 9-15 (2016). https://doi.org/10.1016/j.renene.2016.05.011.

34. López-linares,. Romero, I., Cara, C., Castro, E.; Xylitol production by Debaryomyces hansenii and Candida guilliermondii from rapeseed straw hemicellulosic hydrolysate. Bioresour Technol. 247 736-743 (2018).

35. Ebrahimi, M., Villaflores, O.B., Ordono, E.E., Caparanga, A.R.; Effects of acidified aqueous glycerol and glycerol carbonate pretreatment of rice husk on the enzymatic digestibility , structural characteristics , and bioethanol production. Bioresour Technol 228, 264-271 (2018).

36. , Hickert, L.R., Hector, R., Ayub, M.A.Z.; Fermentation of oat and soybean hull hydrolysates into ethanol and xylitol by recombinant industrial strains of Saccharomyces cerevisiae under diverse oxygen environments. Ind. Crops Prod. 113 10-18 (2018).

37. Patel, H., Chapla, D., Shah, A.; Bioconversion of pretreated sugarcane bagasse using enzymatic and acid followed by enzymatic hydrolysis approaches for bioethanol production. Energy 109, 323-331 (2017). 
Figures
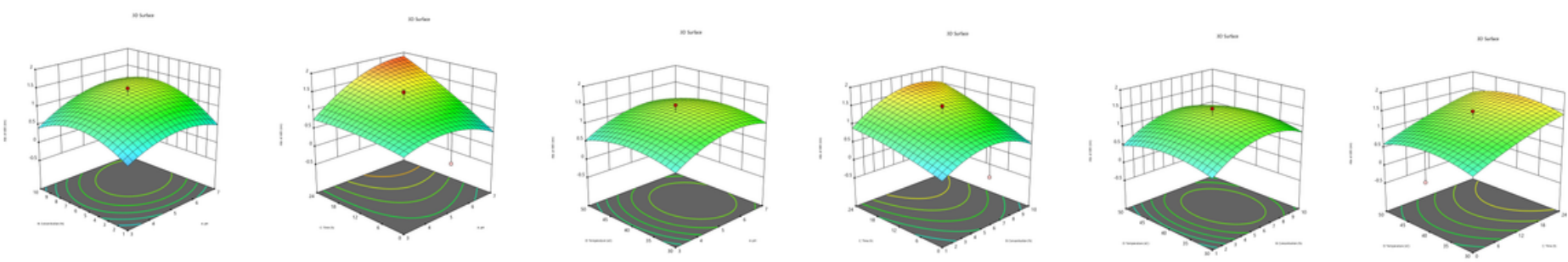

\section{Figure 1}

The 3D surface plots showing the optimization of several parameters (a) $\mathrm{pH}$ and concentration (b) $\mathrm{pH}$ and time (c) $\mathrm{pH}$ and temperature (d) concentration and time (e) concentration and temperature (f) time and temperature on growth of Burkholderia sp SMB1 for the production of enzymes.
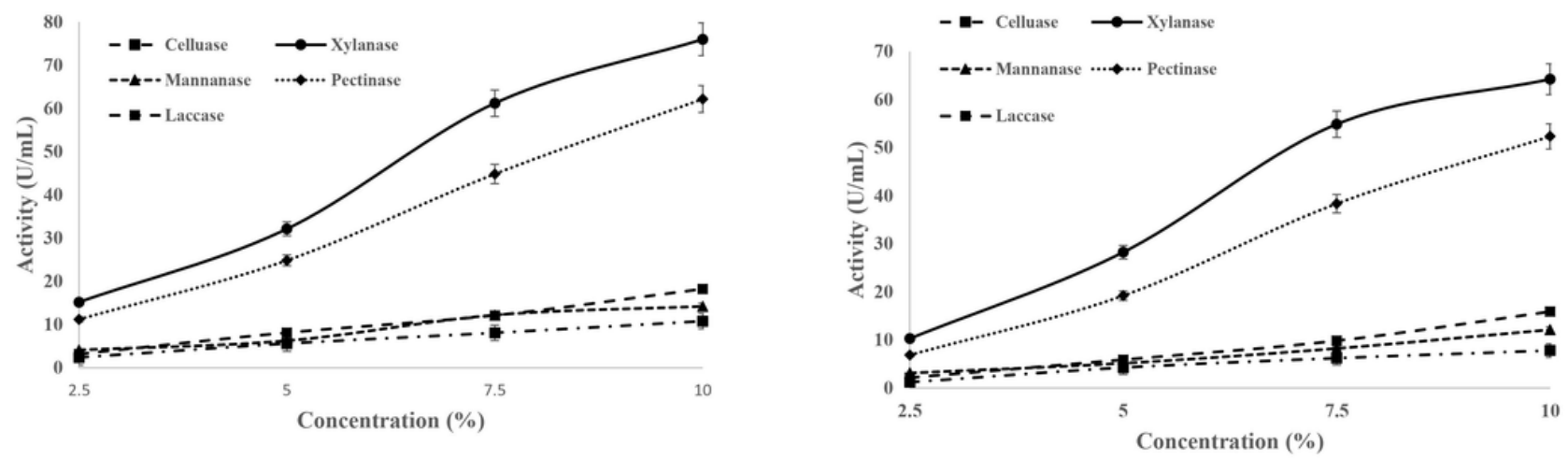

Fig 2a

\section{Figure 2}

Optimization of the concentration of (a) rice bran and (b) rice straw for the production of cocktail of lignocellulolytic enzymes by Burkholderi sp. 

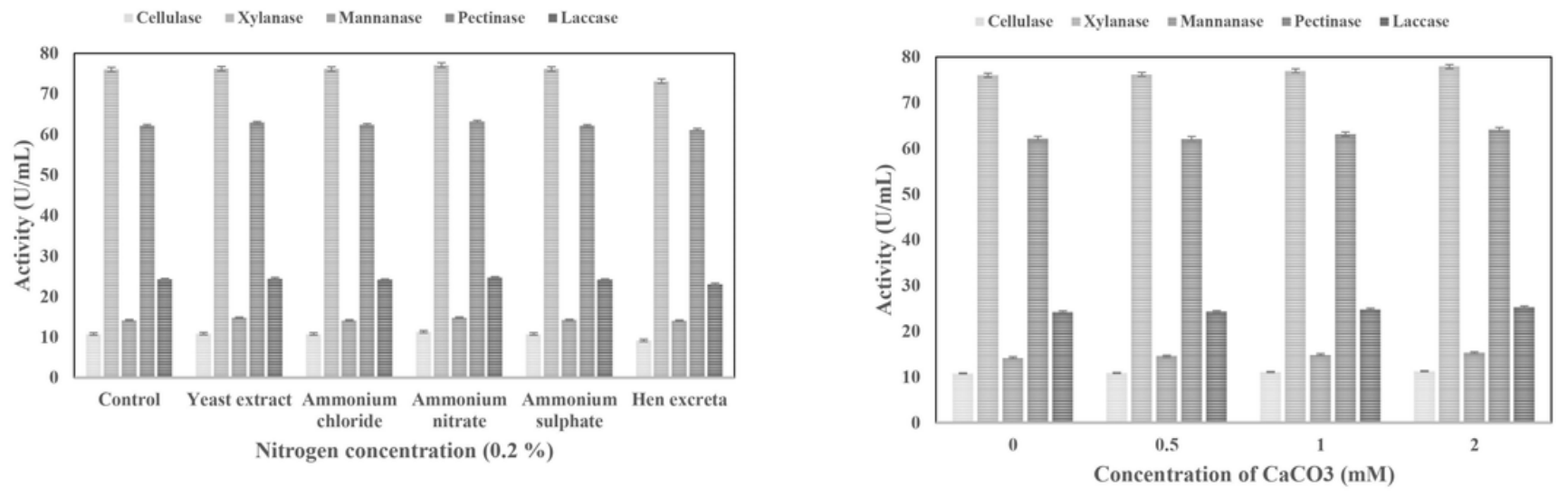

Fig 3a

Fig $3 \mathbf{b}$

\section{Figure 3}

Effect of (a) different nitrogen sources $(0.2 \% \mathrm{w} / \mathrm{v})$ and $(\mathrm{b})$ varying concentration of $\mathrm{CaCO} 3$ on the production of cocktail of lignocellulolytic enzymes secreted by Burkholderia sp. 


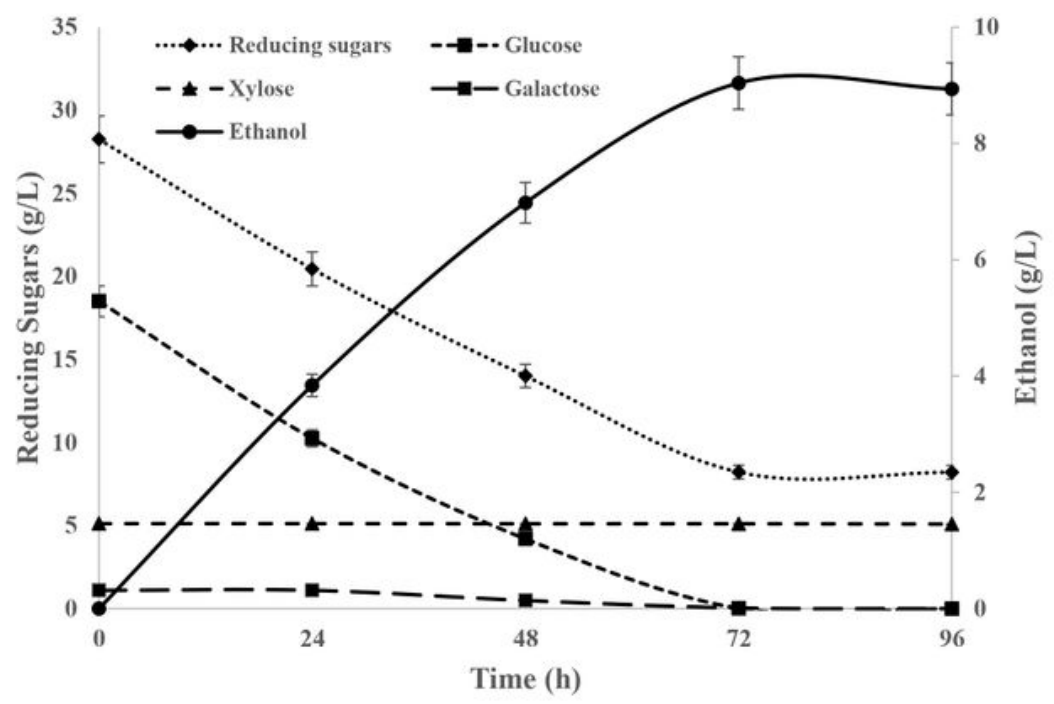

Fig 4

\section{Figure 4}

Utilization of the mono sugars present in the enzymatic hydrolysate of untreated corn husk for bioethanol production 